Vol. 8(5), pp. 55-69, April 2016

DOI: $10.5897 / J E N E 2015.0547$

Article Number: D08709158233

ISSN 2006-9847

Copyright (c) 2016

Author(s) retain the copyright of this article

http://www.academicjournals.org/JENE

\section{Journal of Ecology and the Natural Environment}

\title{
Floristic composition and plant community types of Agama Forest, an "Afromontane Forest" in Southwest Ethiopia
}

\author{
Admassu Addi ${ }^{1 *}$, Teshome Soromessa ${ }^{2}$, Ensermu Kelbessa ${ }^{1}$, Abyot Dibaba ${ }^{1}$ and \\ Alemayehu Kefalew ${ }^{1}$ \\ ${ }^{1}$ College of Natural Sciences, Department of Plant Biology and Biodiversity Management Addis Ababa University, P. O. \\ Box 3434, Addis Ababa, Ethiopia. \\ ${ }^{2}$ Center for Environmental Science, Addis Ababa University, and P. O. Box No: 1176, Addis Ababa, Ethiopia.
}

Received 27 November, 2015, Accepted 23 February, 2016.

\begin{abstract}
Tropical Afromontane forests are among the most species-rich ecosystems on earth and comprise exceptional species richness and high concentrations of endemic species. The natural forest of Agama, an Afromontane forest, was studied with the objectives of determining its species composition, diversity and community types. Systematic sampling design was used to collect vegetation data. Soil samples were taken from each relevé at a depth of 0 to $30 \mathrm{~cm}$ and soil $\mathrm{pH}$, sand, clay and silt were analyzed. The plant communities' classification was performed using the hierarchical cluster analysis. We evaluated species richness, eveness (Pielou $J$ ' index) and diversity (Shanon-Wiener index). Sorensens's similarity ratio was used to compare Agama forest with other similar forest in Ethiopia. A total of 162 plant species, 130 genera and 70 families were recorded from which Acanthaceae and Rubiaceae were the richest families. Furthermore nine endemic plant species were identified. In this study, four plant community types were identified and described. Post-hoc comparison of means among the community types showed that altitude was differed significantly between community types, indicating altitude is the most important factor in determining community type. Phytogeographical comparison of Agama Forest with other vegetation using Sorensens's similarity ratio revealed the highest similarity with Masha and Godre forest. In conclusion Agama forest presents high richness, diversity and endemism, with different plant communities according to altitude. Thus conservation of plant biodiversity is highly recommended.
\end{abstract}

Key words: Diversity, altitude, phytogeography, richness, endemism.

\section{INTRODUCTION}

Afromontane vegetation is an archipelago-like centre of endemism and confined in mountains of Africa. The Afromontane region comprises about 4000 plant species, of which about 3000 are endemic to regions (White, 1983). The largest concentrations of Afromontane vegetation found in Ethiopian highlands and very recently

*Corresponding author. E-mail: admassuaddi@gmail.com.

Author(s) agree that this article remains permanently open access under the terms of the Creative Commons Attribution License 4.0 International License 
this region was designated as the "Eastern Afromontane hotspot," which is one of the 34 regions globally important for biodiversity conservation (Conservation International, 2005). The Ethiopian highlands are the largest mountain complex in Africa and comprise over $50 \%$ of the African land area covered by Afromontane vegetation (Tamrat Bekele, 1994;Demel and Tamrat 1995). The Afromontane vegetation of Ethiopian highlands comprises a center of plant biodiversity and endemism (Vivero et al., 2004) due to variation in climate and altitude. Altitudes of the country range from $125 \mathrm{~m}$ below sea level in the Dallol depression to 4,620 m above sea level at Ras Dejen. As a result, the country possesses rich biodiversity that occur from the highest mountain to the lowlands. Accordingly, the flora of Ethiopia is estimated to contain between 6,500-7,000 species of higher plants, out of which about $12 \%$ are endemic (Tewolde, 1991).

These floral resources found in different vegetation types comprising in forests, woodlands and bush lands and others. The flora of Ethiopia have been investigated by several scholars since the beginning of the $19^{\text {th }} \mathrm{C}$ to the mid of the $20^{\text {th }} \mathrm{C}$. Some studies have provided substantial contribution to describe vegetation types of Ethiopia. Pichi-Sermolli (1957); Chaffey (1979); Friis (1992); Sebsebe et al. (1996); Zerihun (1999); Friis and Sebsebe (2001) and Sebsebe et al. (2011).These studies were carried out in different parts of the Ethiopia and contributed in generating valuable botanical information for the Ethiopian flora.

The vegetation composition and structure of forests in southern and southwestern part of the country was also studied Lisane work Negatu L., (1987); Kumlachew and Tamrat (2002); Tadesse (2003); Feyera (2006); Ensermu and Teshome (2008). These studies have described floristic composition and analyzed plant communities and their relation with environmental factors. According to above studies several plant communities were identified, with characteristic plant species of Ilex mitis, Syzygium guineense, Pouteria adolfi-friederici, Olea welwitschii, Psychotria orophila, and Schefflera abyssinica in southwest Ethiopia. These species are also reported by (Friis, 1992) as the characteristic species of Afromontane rainforest in southwest Ethiopia. The vegetation of southwest Ethiopia varies with altitude and affecting the diversity of plant species. The study of variation of modern pollen rain (Bonnefille et al., 1993) along the ecological gradients containing range of vegetation types in southwest Ethiopia. This indicated that the vegetation types vary with altitude and altitudinal variation is an important environmental factor contributing for diversity of vegetation communities. Afromontane forests are the place of origin of the Coffea arabica and encompass a variety of commercially valuable spices and honey from wild bee. Furthermore the forests also play a pivotal role in providing water resources for the flow of the BaroAkobo river system which is an important tributary of the Nile and it accounts for $42 \%$ of the water in the White
Nile (NTFP, 2006). It is also important for carbon sequestration which has implications for climate change management.

In spite of the ecological and economic role of Ethiopian forests, the forest cover of Ethiopia has declined by human impact. About $35 \%$, of the country's area was once covered by natural high forests, (EFAP, 1994). By the early 1950s, high forests were reduced to $16 \%$ and the country's forests have declined at fast rate and reached $3.6 \%$ by $1980,2.6 \%$ by 1987 (IUCN, 1990), $2.4 \%$ in 1992, (Sayer et al., 1992), and were finally reduced to $2.3 \%$ in 2003 (Shibru, 2003). Because of this shrinkage of the forest resources, most of the remaining forests of Ethiopia are restricted to the south and southwest parts of Ethiopia, which are less accessible, and less populated (Kumelachew and Tamrat, 2002). These forests are continuously threatened by human activities such as clearing forest for coffee and tea plantation, subsistence farming and periodic movements of immigrants from northern and southern parts of Ethiopia looking for fertile land, resulting in the loss of forest cover in the region.

Recognizing the above mentioned threats to forest biodiversity of afromontane rain forests, the government designed different strategies to conserve the remaining forest resources in the region. Participatory forest management (PFM) was one of the solutions to solve the problem of open access to forest resources and to promote sustainable forest management. For instance farm-Africa introduced the Participatory Forest Management approach in southwest Ethiopia particularly in Bonga and the implementation process has been developed since 1996. Agama forest is part of Bonga forest delineated for PFM since 1996 (Aklilu et al., 2014). Though the forest has been under protection since its demarcation, still it has been continuously exploited for agricultural land expansion, timber harvesting, firewood collection and charcoal production due to lack of awareness on principles of PFM. Botanical assessment such as inventory of floristic composition, providing information on species diversity and community structure is necessary for the forest management and sustainable resource utilization by the community members. Therefore the current study aimed to assess the floristic composition and diversity of an Afromontane forests (Agama forest), to analyze community types of the forest and to evaluate the ecological relationships between plant communities and environmental parameters and to analyze phytogeographical relationship of Agama forests with other similar Afromontane forests types in Ethiopia and finally to recommend conservation action for protecting the forest biodiversity of the region.

\section{MATERIALS AND METHODS}

\section{Descriptions of the area}

The Agama forest is part of eastern African Biodiversity hot spot 

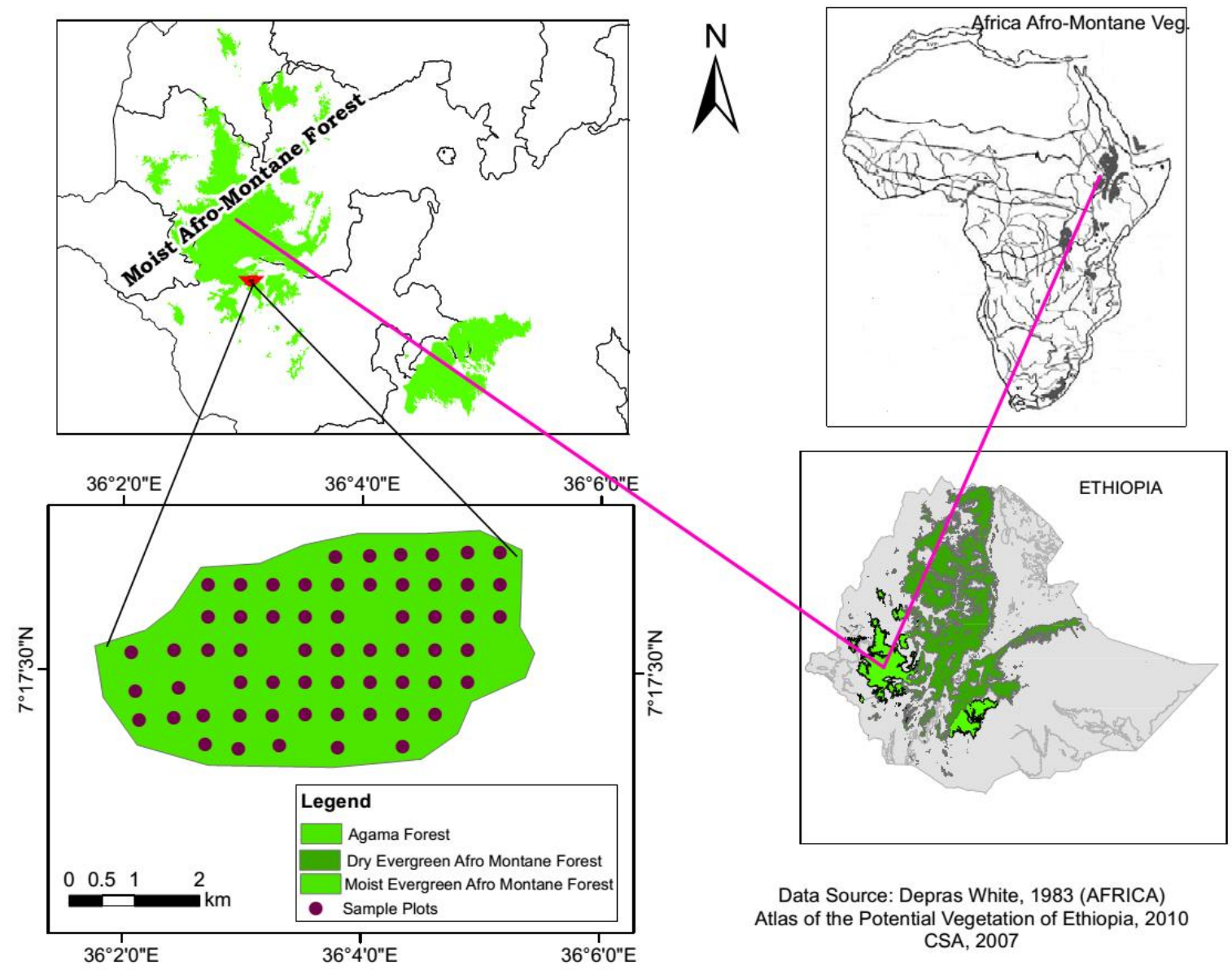

Data Source: Depras White, 1983 (AFRICA) Atlas of the Potential Vegetation of Ethiopia, 2010 CSA, 2007

Figure 1. Location Map of Agama forest

and located in east Africa, in southwest Ethiopia (Figure 1) and it has a total area of $1868.5 \mathrm{ha}$. The area lies at $7^{\circ} 16^{\prime} \mathrm{N}$ and $36^{\circ} 11^{\prime} \mathrm{E}$, and altitude between $1700 \mathrm{~m}$ to 2370 m.a.s.l. (Aklilu et al., 2014). The Geology of area belongs to the Precambrian basement complex, the Tertiary Volcanic Rocks from the trap series, and Quaternary Sediments consists of a variety of sedimentary, volcanic and intrusive rocks (Tafesse, 1996). The major soil groups, according to the FAO/UNESCO legend of soil classification, are Nitisols, Acrisols and Vertisols (Anon., 1988).

The vegetation of the area belongs to Afromonatin rain forest and transitional rain forests (Friis et al., 2011). The forest was stratified into four different layers, namely, upper canopy, sub-canopy, shrub layer and the ground layer and Pouteria adolfi-friederici occupied emergent trees of the upper canopy. The area receives very high annual rainfall reaching up to $1830 \mathrm{~mm}$ in some peak years. The rainfall pattern shows low rainfall in January and February, gradually increasing to the peak period in July and then decreasing in November and December. Maximum and minimum monthly mean temperatures of the area are 26.6 and $9.5^{\circ} \mathrm{C}$ respectively.

\section{Data collection}

A systematic sampling design was used to collect vegetation and environmental data, following Kent and Cooker (1992). Vegetation data were collected using quadrates of $25 \mathrm{~m} \times 25 \mathrm{~m}\left(625 \mathrm{~m}^{2}\right)$, for woody plant species within which a $2 \mathrm{~m} \times 2 \mathrm{~m}$ sub-plot was used for recording herbaceous species and soil sample collection. Ten line transect were established and the distance between each transect was $1 \mathrm{~km}$. The vegetation was sampled following the transect and located at $1 \mathrm{~km}$ apart and were laid systematically at every $500 \mathrm{~m}$. The number of plots per transect is vary depending on length of the transect and accessibility of the sample plots. All level of altitudinal ranges starting from $1700 \mathrm{~m}$ up to $2300 \mathrm{~m}$ were covered during the sampling. A total of 60 releves were sampled and all vascular plant species found in each relevé were recorded and identified. The cover of all the vascular plant species found in each relevé was estimated and rated according to modified 1-9 Braun Blanquet approach (Vander, 1979). The specimens were collected and identified at the National Herbarium (ETH), Addis Ababa University using the published volumes of Flora Ethiopia and Eritrea by comparing with the authentic specimens in the National Herbarium.

\section{Environmental data and soil analysis}

The environmental parameters recorded in this study were altitude, slope, aspect, disturbance, soil pH and soil texture (sand, silt, clay), Altitude was measured by Garmin GPS and slope and aspect were measured using Silva Clinometer and 15T Silva Ranger Compass respectively. Soil analysis was performed in the soil laboratories of 
Addis Ababa University, following the procedures, (Sahlemedhin and Taye, 2000). The soil samples were analyzed for texture, using Hydrometer method of mechanical analysis and Sodium hexametaphosphate were used as dispersing agent. The $\mathrm{pH}$ measure was taken using Digital $\mathrm{pH}$ meter and it was standardized using buffer solutions of $\mathrm{pH} 4.0$ and 9.2. Disturbance was determined on the basis a five point scale following Anderson and Currier (1973). Disturbance scores were based on visible signs of, tree cutting, grazing and presence of beehives. The points of scale were $0-5$, with $0=$ (No disturbance), $1=(0-20 \%$ of the quadrat disturbed), $2=(21-40 \%$ of the quadrat disturbed $), 3=(41-60 \%$ of the quadrat disturbed $), 4=(61-80 \%$ of the quadrat disturbed $), 5=(81$ $100 \%$ of the quadrat disturbed).

\section{Phytogeographical comparison}

Agama forest was compared with five other afromontane rain forests in Ethiopia for the purpose of investigating forest similarity and differences among the afromontane rainforests of Ethiopia. These included Godre,Gera, Masha, Harenna, Jibbat and Yayu. Godre and Masha forests are close to Agama forest found in Bench Maji and Sheka zones in Southern Ethiopia Nations and Nationalities People's Regional State. Jibbat forest is a transitional forest between dry evergreen afromontane and moist evergreen afromontane forest and found in western Shewa in Oromia region. Harenna Forest is located in the Bale Mountain National Park in south eastern Ethiopia.

\section{Data analysis}

An agglomerative Hierarchical Cluster Analysis was performed using Similarity Ratio (S.R), using $R$ software version 2.1.5.2 (Venables et al., 2012). The cut point of the Clusters was decided after visual inspection of the level of aggregation/homogeneity of relevé. Plant community types were further refined in a Synoptic table. The resulting groups were recognized as community types and the species occurrences were summarized by synoptic cover abundance values. The community types were named based on the tree and shrub with high synoptic value.

Ordination was computed using Detrended Correspondence Analysis (DCA) is a technique that is used to display sample plots (sites). In DCA similar samples are plotted close together and dissimilar samples are placed far apart (Hill et al., 1980) (Figure 4). Richness was calculated and Shannon and Wiener (1949) index was applied to quantify species diversity. Shannon diversity index $\left(\mathrm{H}^{\prime}\right)$ was based on frequency of species $H=\sum_{i}^{S}$ pilnpi Where, "H" = Shannon and Wiener diversity index, $\mathrm{S}=$ number of the species $\mathrm{Pi}=$ the proportion of individuals or the abundance of species $i^{\text {th }}=$ the proportion of total cover in the sample and In = natural logarithms. The Pielou's (1966) $\mathrm{J}$ ' evenness index $(\mathrm{J})$ was calculated using the formula: $J=\frac{H}{\operatorname{In}(S)} \quad$ where $J=$ evenness $H^{\prime}=$ Shannon-Wiener Diversity Index $\mathrm{S}=$ total number of species in the sample and $\mathrm{In}=$ natural logarithms.

A similarity analysis was carried out to evaluate the relationship between forests based on presence of trees, shrubs and herbs. Evaluation was conducted using Sorensen's similarity index. It is described using the following formula (Kent and Coker, 1992). Ss = $2 \mathrm{a} /(2 \mathrm{a}+\mathrm{b}+\mathrm{c})$, Where, Ss = Sorensen's similarity coefficient $\mathrm{a}=$ Number of species common to both samples; $b=$ Number of species in sample 1; $c=$ Number of species in sample 2. All the environmental parameters such as altitude, slope, aspect, disturbance and soil data were analyzed as follows: aspect was codified according to Zerihun Woldu et al. (1989): $\mathrm{N}=0$; $\mathrm{NE}=1 ; \mathrm{E}$ $=2 ; \mathrm{SE}=3 ; \mathrm{S}=4 ; \mathrm{SW}=3.3, \mathrm{~W}=2.5 ; \mathrm{NW}=1.3 ;$ Ridge top $=4$. In order to examine the significant differences and similarities between the community types identified, Tukey's multiple tests were performed to detect significant differences between the community types for different environmental parameters (altitude, slope, aspect, and $\mathrm{pH}$ and soil texture). Pearson's correlation was calculated to evaluate the relationship between the environmental parameters, anthropogenic disturbances (timber, charcoal and encroachment and grazing).

\section{RESULTS}

\section{Floristic composition and endemic plants}

A total of 162 plant species (Annex I) belonging to 130 genera and 70 families were recorded and identified in the sample plots in Agama forest (Table 1). Herbs, trees, shrubs, and liana, constituted 50.95, 24.34, 17.19 and $7 \%$ of species abundance respectively (Figure 2 ). Acanthaceae was the richest family representing $8.44 \%$ of total floristic composition, followed by Rubiaceae and Asteraceae with $6.49 \%$ of species. Euphorbiaceae (4.01\%), Roseaceae (3.06\%), and Poaceae (3.08\%) were also important families in terms of species richness. The remaining families represented less than $3 \%$ of species each. Based on the information available on the published Floras of Ethiopia and in Vivero et al. (2005) a total of 9 endemic plant species were recorded (Table 2), comprising more than $5.73 \%$ of the recorded species.

\section{Plant community types}

A total of 162 clusters were derived from the output at dissimilarity level above 0.80 (Figure 3 ). These clusters were designated as local plant community types and given names after two dominating woody species, usually a tree and a shrub with higher synoptic value (Table 3 ). The cluster numbers in the dendrogram correspond to the community types. The description of the plant community types is based on the dominant and characteristic species.

Community I: Macaranga capensis-Sapium ellipticum community-This community type is distributed between the altitudinal ranges of $1945-2343 \mathrm{~m}$ a.s.l. and the slope gradient vary 30 to $65 \%$. It is dominated by the upper canopy of, Macaranga capensis,Sapium ellipticum, Allophylus abyssinica, Apodytes dimidiata, Ficus sur and Croton macrostachyus. The shrubs and herbs include Galiniera saxifraga, Flacourtia indica, Buddleja polystachya, Canthium oligocarpum, Aframomum corrorima, Desmodium repandum, Piper capense and Aspilinum anisophylum are the major plant species found in this community. The climbers/lianas of this community are Tilicora rouplii,Culcasia falcifolia and Vernonia wollastonii. Some of the plant species in this community like Cyathea manniana and Phonix relinata are found along the small streams.

Community II: Millitia ferruginia-Olea capensis community-This community is found between 1781-2085 
Table 1. Plant Families with their number of genera and species occurred in Agama forest.

\begin{tabular}{|c|c|c|c|c|c|c|c|}
\hline Family & Genera & Species number & $\%$ & Family & Genera & Species number & \% Richness \\
\hline Acanthaceae & 10 & 14 & 8.58 & Fabaceae & 5 & 6 & 4.01 \\
\hline Adianthaceae & 1 & 1 & 0.61 & Flacourtiaceae & 1 & 1 & 0.61 \\
\hline Amaranthaceae & 1 & 1 & 0.61 & Myrtaceae & 1 & 1 & 0.61 \\
\hline Amaryilidaceae & 1 & 1 & 0.61 & Moraceae & 2 & 4 & 2.45 \\
\hline Apiaceae & 1 & 1 & 0.61 & Icaccinaceae & 1 & 1 & 0.61 \\
\hline Apocynaceae & 1 & 1 & 0.61 & Lamiaceae & 2 & 2 & 1.22 \\
\hline Araceae & 1 & 1 & 0.61 & Lauraceae & 1 & 1 & 0.61 \\
\hline Araliaceae & 2 & 2 & 1.22 & Oleaceae & 2 & 3 & 1.94 \\
\hline Asclepiadaceae & 1 & 2 & 1.22 & Orchidaceae & 4 & 4 & 2.45 \\
\hline Asparagaceae & 1 & 2 & 1.22 & Pittosporaceae & 1 & 1 & 0.61 \\
\hline Asteraceae & 6 & 10 & 6.13 & Piperaceae & 2 & 2 & 1.22 \\
\hline Boraginaceae & 2 & 2 & 1.22 & Plantaginaceae & 1 & 1 & 0.61 \\
\hline Caryophylaceae & 1 & 1 & 0.61 & Polygonaceae & 1 & 1 & 0.61 \\
\hline Celastraceae & 1 & 1 & 0.61 & Poaceae & 4 & 5 & 3.08 \\
\hline Combreataceae & 1 & 1 & 0.61 & Primulaceae & 1 & 1 & 0.61 \\
\hline Commelinaceae & 1 & 1 & 0.61 & Rhamnaceae & 1 & 1 & 0.61 \\
\hline Cucurbitaceae & 2 & 2 & 1.22 & Ranuaculaceae & 2 & 3 & 1.94 \\
\hline Cyperaceae & 2 & 3 & 1.84 & Rhizophoraceae & 1 & 1 & 0.61 \\
\hline Dracenaceae & 1 & 3 & 1.84 & & & & \\
\hline Euphorbiaceae & 6 & 6 & 4.01 & & & & \\
\hline Loganiaceae & 1 & 1 & 0.61 & Selaginellaceae & 1 & 1 & 0.61 \\
\hline Malvaceae & 2 & 2 & 1.22 & Scrophulariaceae & 1 & 1 & 0.61 \\
\hline Melistostomaceae & 1 & 1 & 0.61 & Spindaceae & 1 & 1 & 0.61 \\
\hline Melianthaceae & 1 & 1 & 0.61 & Verbenaceae & 1 & 1 & 0.61 \\
\hline Meliaceae & 1 & 1 & 0.61 & Violaceae & 1 & 1 & 0.61 \\
\hline Menispermaceae & 1 & 1 & 1.61 & Verbenaceae & 1 & 1 & 0.61 \\
\hline Rubiaceae & 8 & 10 & 6.13 & Vitaceae & 1 & 1 & 0.61 \\
\hline Roseaceae & 3 & 5 & 3.06 & Ulmaceae & 2 & 2 & 1.22 \\
\hline Rutaceae & 4 & 4 & 2.45 & Zingiberaceae & 1 & 1 & 0.61 \\
\hline Sterculiaceae & 1 & 1 & 0.61 & & & & \\
\hline Spotaceae & 1 & 1 & 0.61 & & & & \\
\hline
\end{tabular}

ma.s.l. and its slope gradient vary 15 to $45 \%$. The most characteristic species of this community are Millettia ferruginea,Vepris dainellii,Albizia gummifera, and Lepidotrichilia volkensii. The shrub layer includes Coffea arabica, Dracaena afromontana, Erythrococca trichogyne. The dominant herbs are Achyranthes aspera, Acanthus eminens, Alecmella abyssinica, Desmodium repandum and the grass Oplismenus hirita. This community is abundant with coffee plants and anthropogenic influences are higher as compared with other communities.

Community III: Syzygium guineense-Olea we/witschii community-This community is found between $1810-2230$ $\mathrm{m}$ a.s.l. and slope gradient vary $12-50 \%$. The indicator species of this community are Olea welwitschii and Syzygium guineense. The tree species include Elaeodendron buchananii, Ekbergia capensis, Olea.capensis and Polyscias fulva. The shrubs are
Bersama abyssinica Cantium oligocarpm, Clausena anisata and Oxyanthus speciosus. The herbs are Alecmella abyssinica, Achryanthes aspera, Hypoestes triflora, Piper capense and Oplismenus hirtellus This community is also dominated with Piper capense, one of the spice plant commonly collected by women for income generation.

Community IV: Vepris dainellii-Schefflera abyssinica-The community is distributed in the altitude range of 1798 $2115 \mathrm{~m}$ a.s.l. and the slope gradient varies 10 to $50 \%$. The emerging dominant tree species in the community are Elaeodendron buchananii, Syzygium guineense, Schefflera abyssinica and Vepris dainellii. The shrubs in this community are Dalbergia lactea,Maytenus gracilipes and Dracaena afromontana. The field layer is dominated by Desmodium repandum, Pteris pteridioides and Asplenium anisophyllum and the climbers include Clematis hirsuta, Landolphia buchananii, Hippocratea 


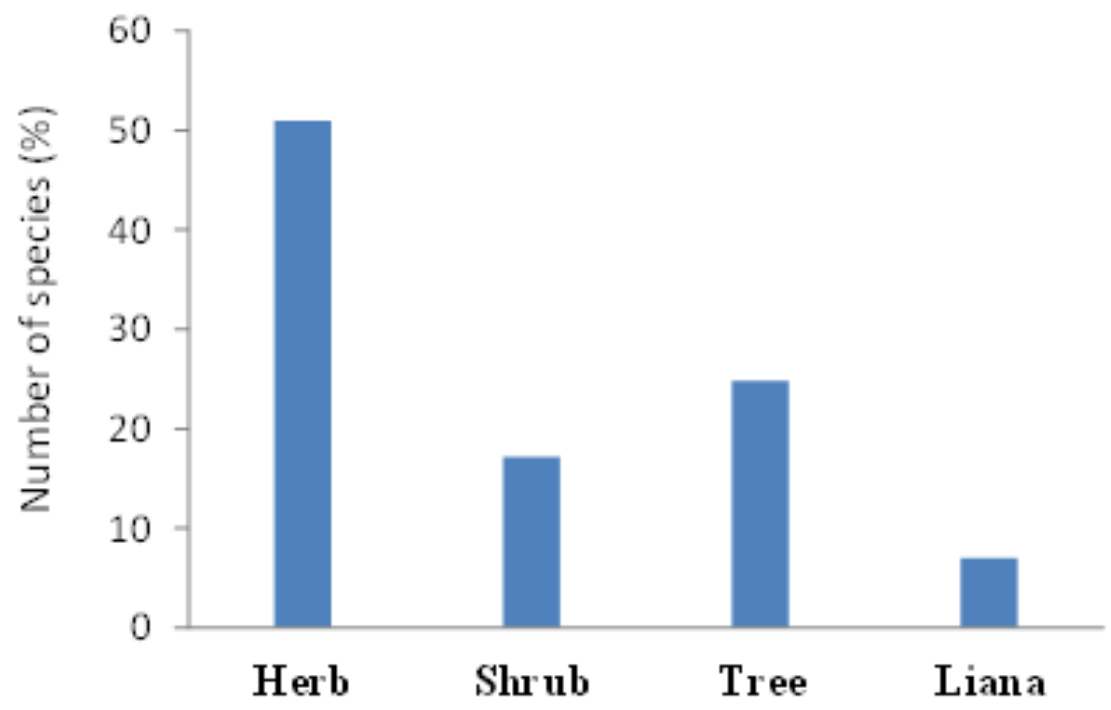

Growth habit

Figure 2. Growth habit of plant species in Agama Forest.

Table 2. Endemic species and their habit in Agama Forest, southwest Ethiopia.

\begin{tabular}{lll}
\hline Species & Family & Habit \\
\hline Aframomum corrorima & Zingeberaceae & Herb \\
Clematis longicauda & Ranunculaceae & Liana \\
Millettia ferruginea & Fabaceae & Tree \\
Pittosporum viridiflorum & Pittosporaceae & shrub \\
Rinorea friisii & Violaceae & Tree/Shrub \\
Scadoxus nutans & Amaryllidaceae & Herb \\
Tiliacora troupinii & Menispermaceae & Climber \\
Vepris dainellii & Rutaceae & Tree/Shrub \\
Vernonia filigera & Asteraceae & Shrub \\
\hline
\end{tabular}

pallens, Jasminum abyssinicum and Urera hypselodendron. This community is comprises important honey tree(Schefflera abyssinica) known for white honey and contributing for the income of the local communities in the area. which needs conservation attention.

\section{Species diversity, richness and equitability}

From analysis of vegetation data using the ShannonWiener diversity index, community II had the highest species diversity (4.18), followed by communities IV (4.08) and III (3.96) and I (3.94). Community II had the highest number of species (110) followed by communities III (103) and IV (103), and I (79). Community I had thehighest evenness value $(0.902)$ followed by communities II (0.89), Community IV (0.88) and III (0.85).

\section{Plant community-environment relationship}

The community types identified from cluster analysis showed significant difference with respect to altitude, slope, soil texture and number of species (Table 4). Community I was significantly different from the rest of the communities in terms of altitude and slope. All the communities identified in this study occur in slightly acidic soils ( $\mathrm{pH} 4$ and 5). There is no significant difference between plant communities for soil $\mathrm{pH}$ and sand content. Community types II differed in clay and silt content from community type 1, 3 and 4 .

The result of Pearson's correlation of the environmental parameters shows that some of the environmental parameters were correlated (Table 5). Altitude is positively correlated with sand with $R^{2}=0.64$ and negatively correlated with clay and silt $(-0.732$ and -0.47$)$ 


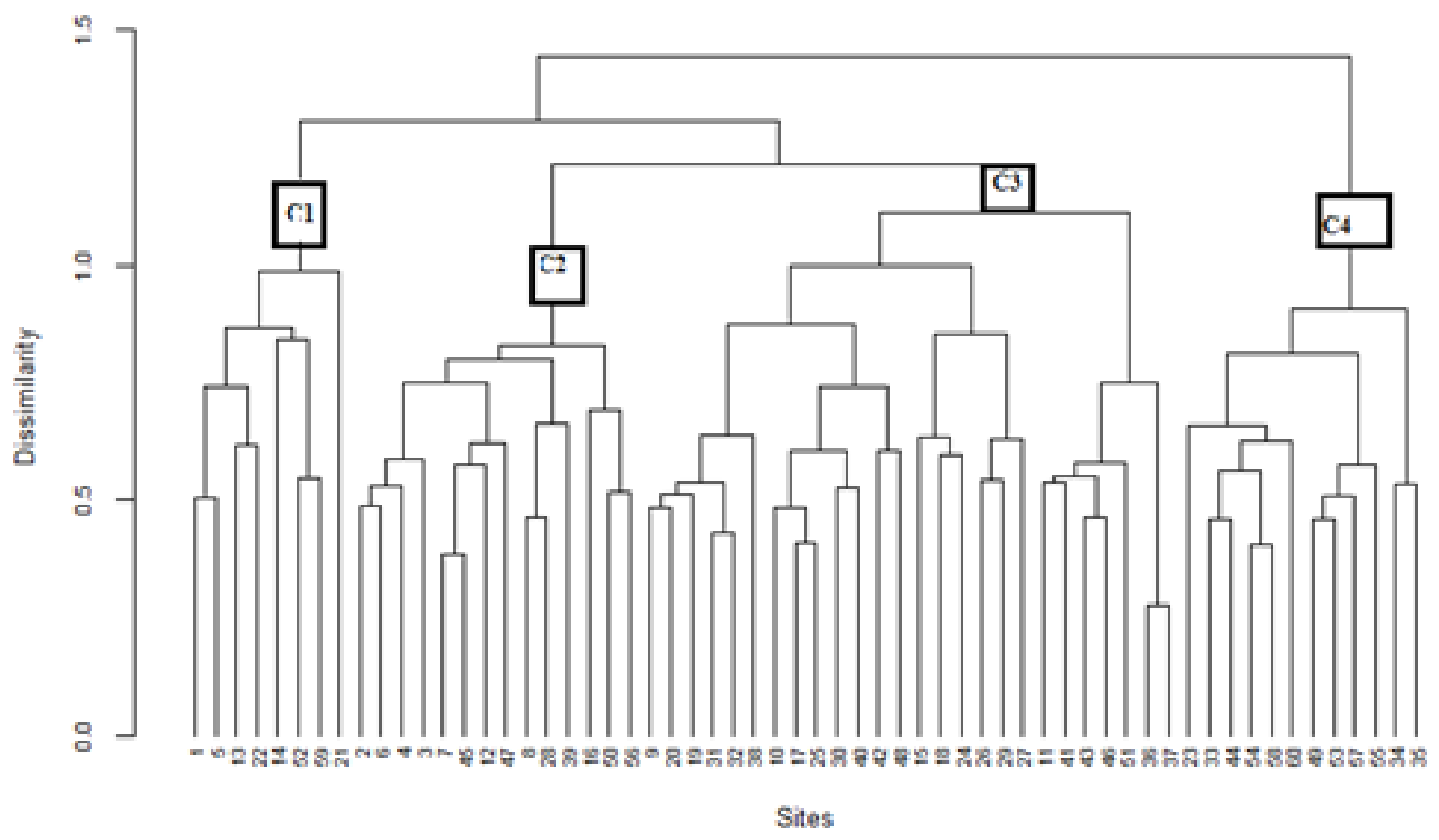

Figure 3. Dendrogram of the cluster analysis results of species abundance found in 60 plots. The plot code and the arrangement of the plots along the dendrogram from left to right are as follows:(C1= Macarnga capensis-Sapium ellipticum, $\mathrm{C} 2=$ Millitia ferruginia-Olea capensis community, $\mathrm{C} 3=$ Syzygium guineense - Olea welwitschii community and C4= Schefflera abyssinica -Vepris dainellii).

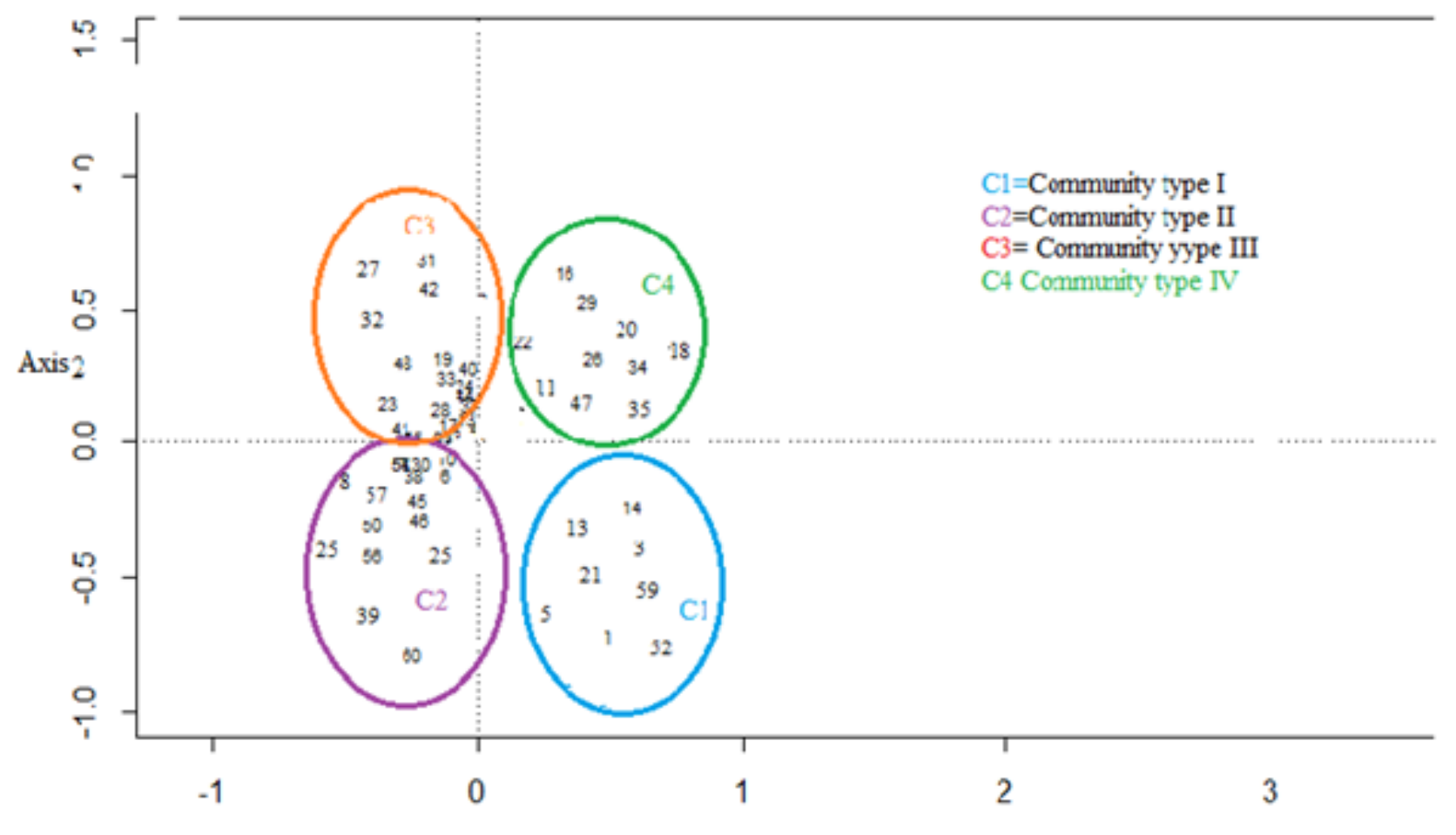

Axis 1

Figure 4. Distribution of relevés on the first and second axis of Detrended correspondence analysis. 
Table 3. Synoptic cover value of plant for species reaching $\geq 1 \%$ in at least one community.

\begin{tabular}{lcccc}
\hline Community type & I & II & III & IV \\
\hline Plot size & 10 & 23 & 19 & 8 \\
Macaranga capensis & $\mathbf{5 . 8 3}$ & 1.65 & 1.30 & 0.00 \\
Sapium ellipticum & $\mathbf{5 . 6 6}$ & 3.13 & 0.80 & 2.5 \\
Cyathea manniana & $\mathbf{4 . 6 6}$ & 0.21 & 0.00 & 0.00 \\
Desmodium repandum & $\mathbf{4 . 5 0}$ & 3.47 & 4.00 & 3.00 \\
Galiniera saxifrage & $\mathbf{4 . 0 2}$ & 2.84 & 2.00 & 2.83 \\
Canthium oligocarpum & $\mathbf{4 . 0 8}$ & 2.57 & 2.80 & 1.83 \\
Phonix reclinata & $\mathbf{4 . 0 1}$ & 3.23 & 0.30 & 4 \\
Ficus sur & $\mathbf{3 . 6 6}$ & 2.26 & 0.20 & 0.66 \\
Allophyllus abyssinicus & $\mathbf{3 . 1 6}$ & 1.52 & 0.30 & 0.00 \\
Ilex mitis & $\mathbf{3 . 5 4}$ & 1.42 & 2.90 & 1.33 \\
Millettia ferruginea & 2.5 & $\mathbf{6 . 8 4}$ & 0.70 & 3.50 \\
Olea capensis & 4.00 & $\mathbf{6 . 3 9}$ & 5.20 & 6.66 \\
Coffea arabica & 2.5 & $\mathbf{4 . 0 2}$ & 0.90 & 2.33 \\
Dracaena afromontana & 2.16 & 3.55 & $\mathbf{3 . 5 0}$ & 3.51 \\
Syzygium guineense & 5.83 & 4.47 & $\mathbf{8 . 1}$ & 5.33 \\
Olea welwitschii & 2.83 & 3.23 & $\mathbf{7 . 9 0}$ & 6.83 \\
Bersama abyssinica & 2.5 & 3.39 & $\mathbf{4 . 6 0}$ & 1.83 \\
Vepris dainellii & 3.66 & 4.21 & 5.70 & $\mathbf{8 . 1 6}$ \\
Schefflera abyssinica & 3.66 & 3.31 & 0.50 & $\mathbf{7 . 5}$ \\
Oxyanthus speciosus & 0.83 & 4.28 & 5.10 & $\mathbf{6}$ \\
Landolphia buchananii & 1.5 & 2.86 & 1.80 & $\mathbf{5 . 1 6}$ \\
Maytenus gracilipes & 0.83 & 2.07 & 3.60 & $\mathbf{4}$ \\
Dalbergia lactea & 2.33 & 0.92 & 0.90 & $\mathbf{3 . 8 3}$ \\
\hline
\end{tabular}

respectively.

\section{Phytogeographical comparison}

The Agama forests in southwestern Ethiopia are floristically related more to the Masha and Godre forest since they are situated in the same climatic region and geographical location. Accordingly Masha and Godere forests share similar Sorensen similarity Index of (0.59) and (0.46) respectively (Table 6). Furthermore Harenna and Jibbat forests are less similar with lower similarity index (0.38 and 0.32 ) respectively.

\section{DISCUSSIONS}

Agama forest is one of the moist Afromontane rainforest and rich in plant biodiversity. It comprises an economically important plants used for coffee, spices and honey. These plant species are Coffee arabica, Aframomum corrorima, Piper capense and Schefflera abyssinica are the most frequent species in almost in all sample plots. Even though the size of the study area was limited; it had high number of plant species which is more or less comparable with that reported for the
Afromontane and transitional rainforest vegetation in southwestern Ethiopia (Kumelachew and Tamrat, 2002) and Gara Ades forest in southeastern Ethiopia (Uhligsit and Uhlig, 1990). Agama forest contains a number of flowering plant species that are endemic to Ethiopia. The endemic plant species identified (9 species) in this study is in agreement with similar studies with Abreham (2009) for Masha Andracha Forest, Derje (2002) for Gura Ferdea forest and Ensermu and Teshome (2008) for Bonga forest. Some of this species are in the IUCN Red Data list, were identified in Agama Forest. The number of endemic plant species recorded for the study area is small compared to dry afromontane forests, since the southwest moist montane forests are poor in trees/shrubs endemicity (Kumelachew and Simon, 2002).

Species diversity and evenness are used to interpret the relative variation among the communities. Lower evenness in Community III indicates the dominance of a few species such as Pouteria adolfi-friedericii (Engl.) Baehni, Schefflera abyssinica (Hochst. ex A. Rich.) Harms, Vepris dainellii (Pichi-serm.) Kokwaro, Dracaena afromontana Mildbr, and Acanthopale aethiogermanica Ensermu in the community and similar observation was reported by Abraham (2009) for Masha forest. On the other hand, high evenness in community I, II and IV indicates little dominance by any single species but 
Table 4. Post-hoc comparison of means between environmental variables and plant community.

\begin{tabular}{lcccc}
\hline \multirow{2}{*}{ Environmental variables } & \multicolumn{4}{c}{ Plant Community Types } \\
\cline { 2 - 5 } & I & II & III & IV \\
\hline Altitude (m) & $2193 \pm 41.37^{\mathrm{b}}$ & $1905 \pm 21.62^{\mathrm{a}}$ & $1960 \pm 25.2^{\mathrm{a}}$ & $1913 \pm 38.95^{\mathrm{a}}$ \\
Slope (\%) & $33.6 \pm 5.3^{\mathrm{b}}$ & $16.3 \pm 2.8^{\mathrm{a}}$ & $14.7 \pm 4.6^{\mathrm{a}}$ & $25 \pm 3.5^{\mathrm{a}}$ \\
Aspect & $1.99 \pm .42^{\mathrm{a}}$ & $2.29 \pm 0.32^{\mathrm{a}}$ & $2.46 \pm 0.43^{\mathrm{a}}$ & $1.3 \pm 0.21^{\mathrm{a}}$ \\
Disturbance & $2.35 \pm 1.88^{\mathrm{a}}$ & $2.36 \pm .20^{\mathrm{a}}$ & $2.66 \pm .21^{\mathrm{a}}$ & $2.15 \pm .24^{\mathrm{a}}$ \\
pH & $4.8 \pm 0.12^{\mathrm{a}}$ & $5.06 \pm 0.106^{\mathrm{a}}$ & $5.22 \pm 0.09^{\mathrm{a}}$ & $4.76 \pm 0.15^{\mathrm{a}}$ \\
Sand (\%) & $66.9 \pm 2.15^{\mathrm{b}}$ & $51.0 \pm 1.8^{\mathrm{a}}$ & $54.4 \pm 2.3^{\mathrm{a}}$ & $48.9 \pm 5.4^{\mathrm{a}}$ \\
Clay (\%) & $18.36 \pm 1.26^{\mathrm{a}}$ & $29.4 \pm 0.85^{\mathrm{b}}$ & $24.9 \pm 1.73^{\mathrm{ab}}$ & $31.4 \pm 3.92^{\mathrm{b}}$ \\
Silt (\%) & $14.65 \pm 1.37^{\mathrm{a}}$ & $21.16 \pm 1.05^{\mathrm{b}}$ & $19.10 \pm 1.18^{\mathrm{ab}}$ & $19.60 \pm 2.02^{\mathrm{ab}}$ \\
\hline
\end{tabular}

Table 5. Pearson's correlation between environmental variables measured in Agama forest.

\begin{tabular}{lcccccccc}
\hline Variables & Altitude & Slope & Aspect & Disturbance & PH & Sand & Clay & Silt \\
\hline Altitude & - & & & & & & & \\
Slope & 0.166 & - & & & & & \\
Aspect & -.005 & 0.043 & - & & & & \\
Disturbance & 0.135 & 0.396 & -0.003 & - & & & \\
PH & -.095 & 0.037 & 0.012 & -0.096 & - & & \\
Sand & $0.640^{* *}$ & -0.115 & -0.219 & $0.67^{* *}$ & 0.013 & - & \\
Clay & $-0.73^{* *}$ & -0.215 & 0.143 & $0.993^{* *}$ & 0.114 & $0.775^{* *}$ & - & - \\
Silt & -0.479 & 0.048 & 0.02 & $-0.583^{* *}$ & 0.109 & 0.882 & 0.549 & - \\
\hline
\end{tabular}

Table 6. Phytogeographical Comparison of Agama forest with other forests in Ethiopia, according to Sorensen similarity Index.

\begin{tabular}{lccl}
\hline Forests & Sorensen index & Dissimilarity & References \\
\hline Godre & 0.46 & 0.54 & Dereje Denu,2006 \\
Masha & 0.59 & 0.41 & Abreham Assefa, 2009 \\
Yayu & 0.40 & 0.60 & Tadesse Woldmariam,2004 \\
Harenna & 0.38 & 0.62 & Lisanework Nigatu,1987 \\
Jibat & 0.32 & 0.78 & Tamart Bekele, 2002 \\
\hline
\end{tabular}

Values in a row with different letters are significantly different $(P<0.05)$.

repeated coexistence of species over all plots in a community (Vepris dainellii). The highest species richness and diversity were observed in community II. The possible reason may be the altitude since it is found at mid altitudes which provides with optimal conditions of environmental factors that favor vegetation growth (Rosenzwieg, 1995). Some species may exclusive to live in mid, low and high altitudes depending on their physiological need and adaption (Austrheim, 2002). Community type I showed the lowest species richness and diversity. This difference is the result of differences in site productivity, habitat heterogeneity and anthropogenic influences such as selective removal of economically important trees and grazing by livestock. Local people reported that this community was used as settlement area for indigenous people before introduction of PFM. The altitude was relatively the important environmental factor that separates the four plant communities studied. Community I was significantly different from the rest of the communities since it is found at higher altitude (2343 $\mathrm{m}$ ) and the communities II, III and IV are found at intermediate altitudes. This study is in agreement with Bonnefille et al. (1993) reported that the presence of altitudinal Zonation is delimiting vegetation types in southwestern Ethiopia and affecting atmospheric pressure, moisture and temperature which have again a strong influence on the growth and development of plants and the distribution of vegetation. Studies by Herdberg in 1951 also confirmed the altitude effect on vegetation in eastern African mountain. 
The acidity of the soil in southwest Ethiopia is relatively higher as compare to other parts of the country due to intense breakdown of organic matter and leaching of the soil by heavy rainfall. This results in leaching of appreciable amounts of exchangeable basic ions like calcium $(\mathrm{Ca})$, magnesium $(\mathrm{Mg})$, sodium $(\mathrm{Na})$ and potassium $(\mathrm{K})$ from the surface of soil (Achalu et al., 2012). The soil pH decreases with increasing altitude and this could affect the chemical reaction between plant roots and nutrients, the availability of nutrients in the soil for plant use and microbial activity (Donahue et al., 1983). These could be the possible reasons for the decline of species richness and diversity with altitude. The differences in soil texture among the communities are not strongly significant due to limited size of the study area and the altitude ranges are not strongly significant to show variation among the plant communities.

The Agama forest was more floristically related to the Masha and Godre forests due to geographical proximity and located in similar climatic zone. Proximity of the areas favors seed dispersal and migration which result in a high floristic similarity. On the other Jibbat and Harenna forests are found in south eastern parts of the country and it has low floristic similarity due to variation in altitude soil, and climatic factors (rainfall, temperature). On top of this human influence on the forest resource also causes variation in floristic diversity. Bonnefille and Hamilton (1986), reported that the destruction of montane forest in southeastern Ethiopia as far back as ca. 2000 years and these historical factors may have led to the variation in floristic diversity between the southwest (Agama) and southeastern (Harenna).

\section{CONCLUSION AND RECOMMENDATION}

The Agama forest, in southwest Ethiopia, has high floristic richness and diversity. Four community types were identified at an altitude between 1800 and $2371 \mathrm{~m}$. The communities at the bottom and middle of the altitudinal gradient were richest while the community restricted to the top had less species. The Soil of Agama forest is acidic (with low $\mathrm{pH}$ ) caused by excessive rainfall. The Agama forest is rich in plant biodiversity as compare to its limited size thus conservation of forest through, strengthening of existing PFM and provision of environmental education for forest user groups are highly recommended.

\section{Conflict of interests}

The authors have not declared any conflict of interests.

\section{ACKNOWLEDGMENT}

The authors highly acknowledged for the financialsupport provided by thematic research division of Addis Ababa University and Biovision foundation. We also thank the
National Herbarium, Addis Ababa University, for letting to utilize the available facilities including flora books and specimens for plant identification.

\section{REFERENCES}

Abraham Assefa (2009). Floristic Composition and Structure of Masha Forest, Southwest Ethiopia. Msc Thesis Addis Ababa University School of Graduate Studies.

Achalu Chimdi, Heluf Gebrekidan, Kibebew Kibret and Abi Tadesse (2012). Effects of Liming on Acidity-Related Chemical Properties of Soils of Different Land Use Systems in Western Oromia, Ethiopia. World J. Agric. Sci. 8(6):560-567

Aklilu Ameha, Larsen HO Mulugeta Lemenih (2014). Participatory Forest Management in Ethiopia: Learning from Pilot Projects. Springer, New York.

Anderson EW, Currier WF (1973). Evaluating zones of Utilization. J. Range Manag. 26(2):87-91.

Austrheim G (2002). Plant diversity patterns in semi-natural grasslands along an elevational gradient in Southern Norway. Plant Ecol. 161:193-205

Bonnefille R. and Hamilton A. C. 1986. Quaternary and late Tertiary history of Ethiopia Vegetation. Symb. Bot. Ups. 26:48-63.

Bonnefille R, Buchet G, Friis I, Ensermu Kelbessa, Mohammed MU (1993). Modern pollen rain on an altitudinal range of forests and woodlands in southwest Ethiopia. Opera Bot. 121:71-84.

Chaffey DR (1979). Southwest Ethiopia Forest Inventory Project, a Reconnaissance Inventory of Forest in South-West Ethiopia. Land Resources Development Centre, Tolworth Tower Surbition Survey, England.

Conservation International (2005). Available at: http://www.conservation.org/

Demel Teketay, Tamrat Bekele (1995). Floristic composition of WofWasha natural forest, Central Ethiopia: implications for the conservation of biodiversity. Feddes Repertorium 106:127-147.

Dereje Denu (2007). Floristic Composition and Ecological Study of Bibita Forest (Guraferda),Southwest Ethiopia. Unpublished MSc. Thesis, Addis Ababa.

Donahue RL, Miller RW and Shikluna JC (1983). Soils. An introduction to soils and plant growth. Prestice Hall of India, New Delhi.

Ensermu K, Teshome S (2008). Interfaces of Regeneration, structure, Diversity and uses of some plants species in Bonga Forest. A Reservoir for wild Coffee Gene Pool. SINET, Ethiopia. J. Sci. 31(2):121-134.

EFAP (1994). The Challenge for Development: Ethiopian Forestry Action Program, Vol.II, Addis Ababa.

Friis I. and Demissew S. (2001). Vegetation maps of Ethiopia and Eritrea. A review of existing maps and the need for a new map for the flora of Ethiopia and Eritrea. Biol. Skr. 54: 399-439.

Feyera Senbeta (2006). Biodiversity and Ecology of Afromontane Rain Forest with Wild Coffea arabica L. Populations in Ethiopia. Dench M, Martius C, Rodgers C (eds.). Ecology Development Series No 38. Bonn.

Friis lb (1992). Forest and forest trees of north-east Tropical Africa. Kew Bull. Additional Ser. 15:1-396.

Friis Ib,Sebsebe D, Paulo van Breugel (2011). Atlas of the Potential Vegetation of Ethiopia. Addis Ababa University Press and Shama books.

Herdberg. O. (1951). Vegetation belts of the East African Mountains. Bot. Tidskr. 45:1 40-202.

Hill MO, Gauch HG (1980). Detrended correspondence analysis: an improved ordination technique. Vegetation 42:47-58.

IUCN (1990).Ethiopia, National Conservation Strategy. Vol. 1, IUCN, Addis Ababa.

Kent M, Coker P (1992). Vegetation Description and Analysis: A Practical Approach. John Wiley and Sons, New York.

Kumlachew Yeshitela and Tamrat Bekele (2002). Plant community analysis and ecology of Afromontane and transitional rainforest vegetation of southwestern Ethiopia. SINET. Ethiop. J. Sci. 25(2):155-175. 
Lisanework N (1987). An Ecological study of the vegetation of the Harenna forest. Unpublished MSc. Thesis, Addis Ababa.

NTFP (2006). Non-Timber Forest Product Research and Development Project Progress Report August 2005 July 2006 Mizan-Teferi, Ethiopia.

Pichi-Sermolli, R. (1957). Una carta geobotanica dell' Africa Orientale (Eritrea, Ethiopia and Somalia) Webbia 12:1 5-132.

Rosenzweig ML (1995). Species Diversity in Space and Time, Cambridge University Press

Sahlemedhin Sertsu and Taye Bekele (2000). Procedures for soil and plant analysis. National Soil Research Organization, Ethiopia.

Sebsebe Demissew, Mengistu Wondafrash and Yilma Desalegn (1996). Forest resources of Ethiopia. In: EWNHS (ed.), Important Bird Areas of Ethiopia. Ethiopian Wildlife and Natural History Society, Addis Ababa. pp. 36-53.

Shibru Tedla (2003). Ethiopian Environmental Condition: Today and Twenty-five Years from Now. Econ. Focus. 5:17-34.

Shannon CE, Wiener W (1949). The Mathematical Theory of Communication. University of Illinois, Chicago, USA.

Simon S. , Girma Balcha (2002). Composition, structure and regeneration status of woody species in Dindin natural forests, southeast Ethiopia: An implication for conservation. Ethiop. J. of Biol. Sci. 3:15-35.

Tamrat B. (1994).Comprehensive Summaries of Uppsala Dissertations from the Faculty of Science and Technology: Studies on Remnant Afromontane Forest on the Central Plateau of Shewa, Ethiopia. Acta Universities Upsaliensis, Uppsala.

Tewolde BG Egziabher (1991). Diversity of Ethiopian flora. In: Engels JMM, Hawkes JG, Melaku W (eds.) Plant Genet. Res. Ethiop. pp. 7581. Cambridge University Press, Cambridge.

Tadesse Woldemariam, (2003).Vegetation of the Yayu Forest in Southwest Ethiopia: Impacts of Human Use and Implications for Insitu Conservation of Wild Coffea arabica L. Populations. Ecology and Development Series No.10.

Tafesse Asres (1996) Agroecological Zones of South western Ethiopia. PhD. Thesis, University of Trier, Germany.

Uhlig S, and Uhlig K, (1990). The floristic composition of a natural montane forest in southeastern Ethiopia. Fed. Rep. 101(1-2):85-88.
Vander Maarel E (1979). Transformation of cover/abundance value in Phytosociology and its effect on community similarity. Vegetation. 39:97-114

Venables WN, Smith DMR, Core Team (1999-2015). An Introduction to R. Notes On R: A Programming Environment for Data Analysis and Graphics.

Vivero JL, Ensermu K, Sebsebe D (2004). Red List of Endemic Flowering Plants of Ethiopia and Eritrea. $5^{\text {th }}$ draft (unpublished). National Herbarium, Addis Ababa University.

White F.(1983). The Vegetation of Africa. A Descriptive Memoir to Accompany the Unesco/AETFAT/UNSO Vegetation Map of Africa. UNESCO, Paris.

Zerihun W (1999). Forest vegetation types of Ethiopia and their status in the geographical context. In: Edwards S, Abebe D, Taye B, Gunther, $\mathrm{H}$. (eds.), Proceedings of the National Forest Genetic Resources conservation Strategy Development Workshop. June 21 -22, Addis Ababa Ethiopia. pp. 1-39.

Zerhun, W. Feoli, E. , Nigatu, L. (1989). Partitioning an elevational gradient of vegetation from southeastern Ethiopia by probabilistic methods. Vegetation 81:189-198. 
Appendix I. checklist of plant species identified from Agama Forest.

\begin{tabular}{|c|c|c|c|}
\hline $\mathbf{S} / \mathrm{N}$. & Plant species & Family & Growth form \\
\hline 1 & Acanthopale ethio-germanica Ensermu & Acanthaceae & Shrub \\
\hline 2 & Acanthopale pubescens (Lindau ex Engl.0.46) C.B. Clarice & Acanthaceae & Herb \\
\hline 3 & Acanthus eminens C.B.Clarke & Acanthaceae & Shrub \\
\hline 4 & Achyrospermum schimperi (Hochst. ex Briq.) Perkins, & Lamiaceae & Herb \\
\hline 5 & Achyranthes aspera L.' & Amaranthaceae & Herb \\
\hline 6 & Adianthum thalictroides schltd & Adianthaceae & Herb \\
\hline 7 & Aerangis brachycarpa ( luch.) Th. Dur.\&Schinz, & Orchidaceae & Herb \\
\hline 8 & Aframomum corrorima (Braun) Jansen & Zingiberaceae & Herb \\
\hline 9 & Ajuga alba (Guerke) Robyns & Lamiaceae & Herb \\
\hline 10 & Albizia gummifera (Gmel.) C.A. Sm. & Fabaceae & Tree \\
\hline 11 & Alblzia schimperiana Oliv. & Fabaceae & Tree \\
\hline 12 & Alecmella fischeri Engl & Roseaceae & Herb \\
\hline 13 & Alecmella abyssinica Fresen & Roseaceae & Herb \\
\hline 14 & Alectra vogelii Benth. & Scrophulariaceae & Herb \\
\hline 15 & Allophyllus abyssinicus (Hochst)Radlk & Spindaceae & Tree \\
\hline 16 & Ammocharis tinneana (Kotschy \&Peyr.)Milne-Redh. & Orchidaceae & Herb \\
\hline 17 & Apodytes dimidiata E. Mey. ex Arn & Icaccinaceae & Tree \\
\hline 18 & Asparagus africanus Lam. & Asparagaceae & Herb \\
\hline 19 & Asparagus setaceus (Kunth) Jessop & Asparagaceae & Herb \\
\hline 20 & Aspilia mossambicensis (Oliv.) Wild & Asteraceae & Herb \\
\hline 21 & Asplenium aethopicum ( Brum.f.) bech & Aspleniaceae & Herb \\
\hline 22 & Asplenium anisophyllum Kunze & Aspleniaceae & Herb \\
\hline 23 & Asplenium bugoiense Hieron & Aspleniaceae & Herb \\
\hline 24 & Asplenium erectum Willd. & Aspleniaceae & Herb \\
\hline 25 & Asplenium friesiorum C.Chr. & Aspleniaceae & Herb \\
\hline 26 & Asplenium sandersonii Hook & Aspleniaceae & Herb \\
\hline 27 & Asystasia gangetica (L.) T. Andders. Subsp. Micrantha (Nees). Ensermu & Acanthaceae & Herb \\
\hline 28 & Bersama abyssinica Fresen. & Melianthaceae & Tree/Shrub \\
\hline 29 & Bothriocline schimperi Olivo \& Hiern ex Benth. & Asteraceae & Herb \\
\hline 30 & Brillantaisia madagascariensis T. Anders. & Acanthaceae & Shrub \\
\hline 31 & Buddleja polystachya Fresen. & Loganiaceae & Tree/shrub \\
\hline 32 & Bulbophyllum josephii (Kuntze) Summerh., & Orchidaceae & Herb \\
\hline 33 & Canthium oligocarpum Hiern & Rubiaceae & Tree \\
\hline 34 & Cassipourea malosona (Baker) Alston & Rhizophoraceae & Tree \\
\hline 35 & Carex chlorosaccus C.B. Clarke & Cyperaceae & Herb \\
\hline 36 & Carex spicato-paniculata Bock. ex C.B. Clarke & Cyperaceae & Herb \\
\hline 37 & Cayratia gracilis (Guill. \& Perr.] Suesseng. & Vitaceae & Herb \\
\hline 38 & Celtis africana Burm. & Ulmaceae & Tree \\
\hline 39 & Chamaecrista mimosoides (L.) Green & Mimosoideae & Liana \\
\hline 40 & Clausena anisata (Wild.) Benth. & Rutaceae & Shrub/Tree \\
\hline 41 & Clematis longicauda Steud. ex A. Rich & Ranuaculaceae & Liana \\
\hline 42 & Clematis simensis Fresen. & Ranuaculaceae & Liana \\
\hline 43 & Coffea arabica L. & Rubiaceae & Shrub/Tree \\
\hline 44 & Cordia africana Lam. & Boraginaceae & Tree \\
\hline 45 & Combretum paniculatum Vent. & Combreataceae & Liana \\
\hline 46 & Commelina diffusa Burm.f. & Commelinaceae & Herb \\
\hline 47 & Coniogramme africana Hieron & Hemionitidaceae & Herb \\
\hline 48 & Crassocephalum crepidioides (Benth.) S. Moore & Asteraceae & Herb \\
\hline 49 & Croton macrostachys Del. & Euphorbiaceae & Tree \\
\hline 50 & Cryptotaenia africana (Hookf) Drude & Apiaceae & Herb \\
\hline
\end{tabular}


Appendix I. Contd.

\begin{tabular}{|c|c|c|c|}
\hline 51 & Cucumis dipsaceus Ehrenb. ex Spach & Cucurbitaceae & Herb \\
\hline 52 & Culcasia falcifolia Engl. & Araceae & Herb \\
\hline 53 & Cyathea manniana Hook. & Cyatheaceae & Tree \\
\hline 54 & Cyperus fischeria A.Rich. & Cyperaceae & Herb \\
\hline 55 & Dalbergia lactea Vatke & Fabaceae & Shrub \\
\hline 56 & Desmodium repandum Vahl & Fabaceae & Herb \\
\hline 57 & Dicliptera maculata Nees, & Acanthaceae & Herb \\
\hline 58 & Didymochlaena truncatula (Sw.) J. Sm & Aspidiaceae & Herb \\
\hline 59 & Dissotis canescens (Graham) Hook.f. & Melistostomaceae & Herb \\
\hline 60 & Dombeya torrida (J.F.Gmel.) Bamps & Sterculiaceae & Tree \\
\hline 61 & Dracaena afromontana Mildbr. & Dracenaceae & Shrub \\
\hline 62 & Dracaena fragrans (L.) Ker-Gawl. & Dracenaceae & Shrub \\
\hline 63 & Dracaena steudneri Scw.ex Engl. & Dracenaceae & Tree \\
\hline 64 & Drynaria volkensii Hieron & Polypodiaceae & Herb \\
\hline 65 & Dryopteris concolor (langsd.\&Fisch.) Kuhn in Vonder Decken & Dryopteridaceae & Herb \\
\hline 66 & Ehretia cymosa Thonn. & Boraginaceae & Tree \\
\hline 67 & Ekebergia capensis Sparrm. & Meliaceae & Tree \\
\hline 68 & Elaeodendron buchananii & Celastraceae & Tree \\
\hline 69 & Elatostemma monticolum Hook. f. & Urticaceae & Herb \\
\hline 70 & Embelia schimperi Vatke & Myrsinaceae & Liana \\
\hline 71 & Erythrococca trichogyne (Muell. Arg.) Prain & Euphorbiaceae & Shrub/Tree \\
\hline 72 & Euphorbia ampiphyla Pax. & Euphorbiaceae & Tree \\
\hline 73 & Ficus sur Forssk. & Moraceae & Tree \\
\hline 74 & Ficus ovata Vahl & Moraceae & Tree \\
\hline 75 & Ficus thonningii Blume & Moraceae & Tree \\
\hline 76 & Fagaropsis angolensis & Rutaceae & Tree \\
\hline 77 & Flacourtia indica (Burm.f.) Merrill & Flacourtiaceae & Tree \\
\hline 78 & Galiniera saxifraga (Hochst.) Bridson & Rubiaceae & Tree \\
\hline 79 & Tacazzea conferta N.E. Br. & Asclpidaceae & liana \\
\hline 80 & Tacazzea apiculata Oliv & Asclpidaceae & liana \\
\hline 81 & Habenaria quartiniana A. \&ch., & Orchidaceae & Herb \\
\hline 82 & Helicbrysum stenoptel1/m DC. & Asteraceae & Herb \\
\hline 83 & Hippocratea pallens Oliv. & Celastraceae & shrub \\
\hline 84 & Holothrix praecox Rchbf. & Orchidaceae & Herb \\
\hline 85 & Hyparrhenia hirta (L.) Stapf, var. brachypoda Chiov. & Poaceae & Herb \\
\hline 86 & Hypoestes forskaolii Roem. \& Schult. & Acanthaceae & Herb \\
\hline 87 & Hypoestes triflora (Forssk.) Soland.ex Roem. \& Schult. & Acanthaceae & Herb \\
\hline 88 & Ilex mitis (L.) Radlk. & Aquifoliaceae & Tree \\
\hline 89 & Indigofera mimosoides Bak. & Fabaceae & Shrub \\
\hline 90 & Isoglossa laxa Oliv. & Acanthaceae & Herb \\
\hline 91 & Isoglossa somalensis Lindau & Acanthaceae & Herb \\
\hline 92 & Jasminum abyssinicum DC. & Oleaceae & Liana \\
\hline 93 & Landolphia buchananii Stapf. & Apocynaceae & Liana \\
\hline 94 & Lepidotrichilia volkensii (Gurke) Leory & Meliaceae & Tree \\
\hline 95 & Loxogramme lanceolata auct,non(sw.) presl & polypodiaceae & Herb \\
\hline 96 & Lycopodium dacrydioides Bak & Lycopodiaceae & Herb \\
\hline 97 & Lysimachia ruhmeriana Vatke & Primulaceae & Herb \\
\hline 98 & Macaranga capensis (Baill.) Sim & Euphorbiaceae & Tree \\
\hline 99 & Maesa lanceolata Forssk. & Myrsinaceae & Shrub /Tree \\
\hline 100 & Maytenus gracilipes (Welw.ex Oliv.) Exell & Celastraceae & Shrub \\
\hline 101 & Mikaniopsis c1ematoides (.S'ch. Bip. ex A. Rich.) Milne-Redh. & Asteraceae & Herb \\
\hline 102 & Millettia ferruginea (Hochst.) Baker & Fabaceae & Tree \\
\hline
\end{tabular}


Appendix I. Contd.

\begin{tabular}{|c|c|c|c|}
\hline 103 & Monothecium glandulosum Hochst., & Acanthaceae & Herb \\
\hline 104 & Ocotea kenyensis (Chiov.) Robyns \& Wilcz & Lauraceae & Tree \\
\hline 105 & Olea capensis subsp. macrocarpa (C. A. Wright) Verdc. & Oleaceae & Tree \\
\hline 106 & Olea we/witschii (Knobl.) Gilg \& Schellenb. & Oleaceae & Tree \\
\hline 107 & Oplismenus hirtellus (L.) P. Beauv. & Poaceae & Herb \\
\hline 108 & Oxyanthus speciosus DC. & Rubiaceae & Shrub \\
\hline 109 & Panicum monticola Hook. f. & Poaceae & Herb \\
\hline 110 & Pavonia urens Cav. & Malvaceae & Shrub \\
\hline 111 & Pavetta abyssinica Fresen. var. abyssinica & Rubiaceae & Shrub \\
\hline 113 & Pentas lanceolata (Forssk.) Defl. & Rubiaceae & shrub \\
\hline 114 & Pentas schimperiana(A.Rich)vatke & Rubiaceae & Herb \\
\hline 115 & Peponium vogelii (Hook.f.) Engl. & Cucurbitaceae & Herb \\
\hline 116 & Peperomia tetraphylla (Forster.) Hook. \& Arn. & Piperaceae & Herb \\
\hline 117 & Phaulopsis imbricata (Forssk.) Sweet & Acanthaceae & Herb \\
\hline 118 & Pittosporum viridiflorum Sims & Pittosporaceae & Shrub \\
\hline 119 & Phonix reclinata Jacq. & Araceae & Tree \\
\hline 120 & Phyllanthus ovalifolius Forssk. & Euphorbiaceae & Herb \\
\hline 121 & Pilea rivularis Wedd. & Urticaceae & Herb \\
\hline 122 & Piper capense L.f. & Piperaceae & Herb \\
\hline 123 & Plantago palmata Hook.f. & Plantaginaceae & Herb \\
\hline 124 & Poecilostachys oplismenoides (Hack.) W. D. Clayton & Poaceae & Herb \\
\hline 125 & Polygonum nepalense Meisn. & Polygonaceae & Herb \\
\hline 126 & Polyscias fulva (Hiern) Harms & Araliaceae & Tree \\
\hline 127 & Pouteria adolfi-friederici (Engl.) Baehni & Sapotaceae & Tree \\
\hline 128 & Premna schimperi Engl. & Verbenaceae & Shrub \\
\hline 129 & Prunus africana (Hook. f.) Kalkm. & Roseaceae & Tree \\
\hline 130 & Psychotria orophila Petit & Rubiaceae & Shrub \\
\hline 131 & Pteris pteridioides (Hook.) ballard & Pteridaceae & Herb \\
\hline 132 & Pycnostachys eminii Gurke, & Lamiaceae & Shrub \\
\hline 133 & Rhamnus prinoides L'Herit. & Rhamnaceae & Shrub/Tree \\
\hline 134 & Rinorea friisii M. Gilbert & Violaceae & Tree \\
\hline 135 & Rothmannia urcelliformis (Hiern) Robyns & Rubiaceae & Tree \\
\hline 136 & Rubus apetalus Poir. & Roseaceae & Shrub \\
\hline 137 & Rubus steudneri Schweinf. & Roseaceae & Liana \\
\hline 138 & Rytignia neglecta (Hiern) Robyns & Rubiaceae & Shrub \\
\hline 139 & Scadoxus multiflorus (Martyn) Raf' & Amarylidaceae & Herb \\
\hline 140 & Sapium ellipticum (Krauss) Pax. & Euphorbiaceae & Tree \\
\hline 141 & Schefflera abyssinica Harms & Araliaceae & Tree \\
\hline 142 & Selaginella kalbreyeri Bak.` & Selaginellaceae & Herb \\
\hline 143 & Setaria megapbylla (Steud.) Th. Dur. \& Schinz & Poaceae & Herb \\
\hline 144 & Sida collina Schlechtend. & Malvaceae & Herb \\
\hline 145 & Stellaria mannii Boolc., & Caryophylaceae & Herb \\
\hline 146 & Stephania abyssinica (Dill \& A. Rich.) Walp & Menispermaceae & Herb \\
\hline 147 & Syzygium guineense (Willd.) DC. & Myrtaceae & Tree \\
\hline 148 & Teclea nobilis Del. & Rutaceae & Shrub/Tree \\
\hline 149 & Thalictrum rhynchocarpum Dill. \& A. Rich & Ranunculaceae & Herb \\
\hline 150 & Tiliacora troupinii Cuf. & Menispermaceae & Liana \\
\hline 151 & Trema orientalls (L) Blo, & Ulmaceae & Tree \\
\hline 152 & Trilepisium madagascariense DC. & Moraceae & Tree \\
\hline 153 & Tristemma mauritianum J. F. Gmel & Melistostomaceae & Herb \\
\hline 154 & Urera hypselodendron (A. Rich.) Wedd., G & Urticaceae & Herb \\
\hline 155 & Vepris dainellii (Pich.-Serm.) Kokwaro & Rutaceae & liana \\
\hline
\end{tabular}


Appendix I. Contd.

156 Vernonia amygdalina Del.

157 Vernonia auriulifera Hiern

158 Vernonia hochstetteri Sch. Bip. ex Walp

159 Vernonia filigera Oliv. \& Hiern

$160 \quad$ Vittaria guineensis Desv

$\begin{array}{ll}\text { Asteraceae } & \text { Tree } \\ \text { Asteraceae } & \text { Shrub/Tree } \\ \text { Asteraceae } & \text { Shrub/Tree } \\ \text { Asteracea } & \text { Herb } \\ \text { Vittariaceae } & \text { Herb }\end{array}$

Asteraceae 